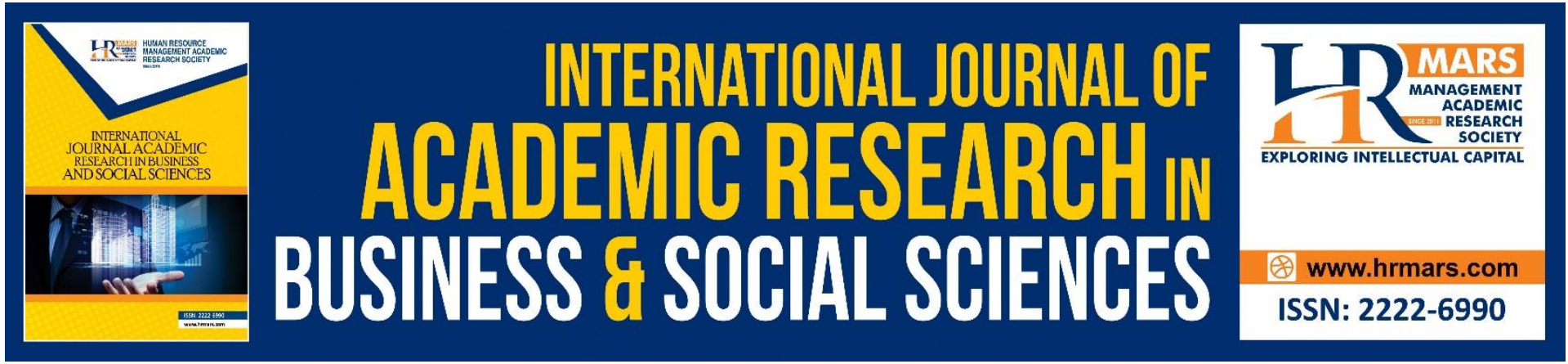

\title{
Constructing a New Stress Index for Teachers in Malaysia
}

\author{
Izzati Zarin, Kuldip Kaur, Shafinar Ismail, Yap Voon Choong, Chew Sze \\ Chiong
}

To Link this Article: http://dx.doi.org/10.6007/IJARBSS/v11-i7/10541

DOI:10.6007/IJARBSS/v11-i7/10541

Received: 18 May 2021, Revised: 22 June 2021, Accepted: 14 July 2021

Published Online: 28 July 2021

In-Text Citation: (Zarin et al., 2021)

To Cite this Article: Zarin, I., Kaur, K., Ismail, S., Choong, Y. V., \& Chiong, C. S. (2021). Constructing a New Stress Index for Teachers in Malaysia. International Journal of Academic Research in Business and Social Sciences, 11(7), 859-863.

\section{Copyright: @ 2021 The Author(s)}

Published by Human Resource Management Academic Research Society (www.hrmars.com)

This article is published under the Creative Commons Attribution (CC BY 4.0) license. Anyone may reproduce, distribute, translate and create derivative works of this article (for both commercial and non-commercial purposes), subject to full attribution to the original publication and authors. The full terms of this license may be seen

at: http://creativecommons.org/licences/by/4.0/legalcode

Vol. 11, No. 7, 2021, Pg. 859 - 863

http://hrmars.com/index.php/pages/detail/IJARBSS

JOURNAL HOMEPAGE

Full Terms \& Conditions of access and use can be found at http://hrmars.com/index.php/pages/detail/publication-ethics 


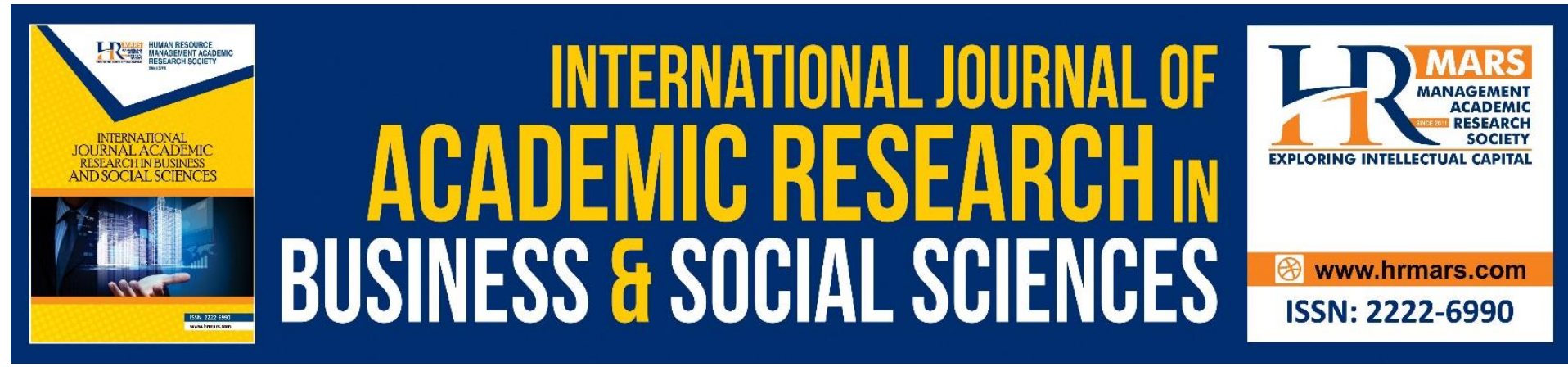

\title{
Constructing a New Stress Index for Teachers in Malaysia
}

\author{
Izzati Zarin ${ }^{1}$, Kuldip Kaur ${ }^{1}$, Shafinar Ismail ${ }^{1}$, Yap Voon \\ Choong ${ }^{2}$, Chew Sze Chiong ${ }^{1}$ \\ ${ }^{1}$ UiTM Kampus Alor Gajah, Malaysia, ${ }^{2} \mathrm{MMU}$ University, Malaysia \\ Email:kksekhon@uitm.edu.my
}

\begin{abstract}
Teachers in Malaysia are suffering from stress, and this issue must be tackled seriously by all interested parties. As teachers play a role in producing good and effective citizen, their stress must be studied and understood. Therefore, this study advocates for a new stress index for Malaysian teachers to better understand teachers' stress. This paper aims to present the findings on teachers' stressors unearthed during the interview with the teachers regarding teachers' stress. In this step, twenty-nine teachers from primary and secondary schools were interviewed to validate the initial constructs of teachers' stressors during the construct definition step, the first step in the Fuzzy-Delphi method. Based on the interview's findings, the interview has corroborated the construct defined in literature research and added two new sub-themes to the stressors' construct. The study concluded that conducting a study on stress through the Fuzzy-Delphi method is crucial because the Fuzzy-Delphi method is a rigorous process to ensure that an index developed would yield high validity and reliability.

Keywords: Stressors, Teachers' Stress, Workplace Stress, Life Stress, Stress Index, Coping Stress, Fuzzy-Delphi Method
\end{abstract}

\section{Introduction}

In this current educational climate, teachers' stress is one of the threats that can disrupt teachers' productivity and well-being in their workplace. The effects of teachers' stress in school have been documented in past literature. For example, past studies have described the effect of workplace stress among teachers in terms of their job satisfaction (Yacob \& Abdullah, 2015; Zarisfizadeh, 2012), health (Masilamani et al., 2012; Musa, Moy, \& Wong, 2018; Zamri, Moy, \& Hoe, 2017) and, mental-being (Othman \& Sivasubramaniam, 2019). Othman, Z. \& Sivasubramaniam, V. (2019), stated that the Ministry of Education reported that 4.23 per cent of teachers were diagnosed with severe stress, while in 2019, the Ministry of Education reported that more teachers had been sent to undergo counselling mental health treatment due to stress. Therefore, it is paramount for teachers and school administrators to outline an effective stress management strategy for teachers to cope with stress and manage stress effectively.

In school, a teacher would face different facets of job responsibilities, and they are compelled to work with numerous people. These people usually embody different personalities, 
positions, power, and skills that may match or mismatch their personalities. Also, teachers must carry frequent interaction and co-operation, and the unbalanced dynamic of these interactions can cause stress at work (Hassard et al., 2018). Not only social interaction, but teachers are also facing challenges in dealing with the school environment and, but students' conducts in school can also cause teachers to stress in the workplace, and this stress can cause a toll on the teachers' physical and mental well-being (Haggard, Slostad, \& Winterton, 2006). In Malaysia, the education system has been through numerous changes over a short time, and these changes have affected the teachers. Another significant factor contributing to teachers' stress is the constant changes in teaching policy, syllabus, and practices, forcing them to acclimate to these changes in a short period with minimal support (Sapidin, 2005).

Aside from workplace stress, teachers are also suffering from personal stress that disrupted their work-life balance. Personal stress is a common issue among employees at work, including teachers; as Goyal and Arora (2012) stated, employees worldwide face challenges balancing their family and work priorities. Teachers need to experience career growth in their work, but day-to-day responsibilities might break the growth. This is further explained by Punia and Kamboj (2013), who stated teachers nowadays could not draw the fine line in balancing their work and life because the boundary of life and work are often blurred. Based on the current situation, it is imperative for Malaysia, particularly the Ministry of Education, the Ministry of Health, and the school administrators, to understand stress among teachers.

In Malaysia, the teachers are under the responsibilities of the Ministry of Education. The responsible unit under the Ministry of Education is the Psychology and Counselling unit for teachers' stress. For the psychometric analysis, the department uses the DASS-21 questionnaire to evaluate stress levels among teachers. The DASS-21 questionnaire is a shortened version of its predecessor, the DASS-42. The DASS-21 questionnaire has twentyone items on a Likert-scale, and it is a popular non-diagnostic, self-reported measure of depression, anxiety, and stress (Lovibond \& Lovibond, 1995). DASS-21 is a powerful instrument to measure stress among teachers, and its reliability and validity have been proven to be effective in measuring stress in a non-clinical sample (Henry \& Crawford, 2005).

This study was founded on the need to construct a stress index for Malaysian teachers using the Fuzzy-Delphi method is needed. This study is not to undermine the contribution of DASS21 in recognising the prevalence of stress among teacher. However, this study is adamant that knowing the causes of stress is just as vital as recognising the presence of stress among teacher. Therefore, a new stress index is vital as it can complement the DASS-21 instrument because the index can recognise the cause of stress among teachers. This study refers to the Fuzzy-Delphi method to construct the stress index. As explained by Liu (2013), the FuzzyDelphi method has four steps that need to be completed to build the new index. The first step of the Fuzzy-Delphi method is called the construct definition method, and during this step, the constructs for the field was established to develop the initial index for teachers' stress. In the Fuzzy-Delphi method, the constructs were defined using an extensive literature review, relevant document studies, and interviews. Therefore, this paper aims to present the findings gathered during the interview with the teachers in the construct definition step.

Based on the aim of the study, this paper posed two research objectives, 1) to identify the causes of teachers' stress among Malaysian teachers and 2) to identify the constructs for the 
causes of stress in the Stress Index for Teachers in Malaysia. Based on the research objectives, the research questions of the paper are:

1) What are the causes of stress among Malaysian teachers?

2) What are the constructs for causes of stress in the Stress Index for Teachers in Malaysia?

\section{Literature Review The Definition of Stress}

The development of stress theories began during the post-war period (Whitehead, 2001). The renowned American Psychologist, Walter Cannon, was the first scholar to apply the word stress in a study to conceptualise a physiological theory of emotions and instincts. Following Cannon's work, Selye extended the study, and his definition of stress becomes the most widely used definition that earned him the moniker of 'father of stress' (Tan \& Yip, 2018). Selye's definition of stress is that stress is the response from the stimuli or known as stressors. As teachers are burdened with schools' responsibilities, and simultaneously, they are managing a busy schedule between work and family, it is conceivable to say that teachers are facing two types of stress, life stress and workplace stress.

Defining life stress is not an easy task since it is a highly complex construct that can cause by various stressors. These stressors can affect the human's well-being differently, and each of them carries unique dimensions in terms of their severity, frequency, timing, and duration (Slavich, 2016). Looking at the duration perspective, stressors can happen in the moment of life events, such as receiving news of health complication, job termination or taking care of dying relatives. Stressors can also be influenced by time or during a person's life. For example, a person would experience a dimension of stressors when studying and, other dimensions of stressors would occur when he graduated. Stressors can also be influenced by a degree of frequency. For example, a person who experienced car breakdown once a year can consider it less stressful than a person who faced a car breakdown every month. Finally, the severity of stressors can be different from one another, and this dimension is difficult to assess because it depends on individual differences, upbringing and other factors. For example, a person who loves to walk might find a long commute to work to be minimal stress, while a person who did not enjoy walk can conceive this long commute as a severe stressor in life (Epel et al., 2018).

Meanwhile, workplace stress is defined as the response people may have when presented with work demands and pressures that are not matched to their knowledge and abilities, which challenge their ability to cope (World Health Organization, 2007). As Hasan, Elsayad, and Tumah (2018) explained, workplace stress commonly happened when a worker felt that the demand presented in the workplace had exceeded the resources to fulfil the demand. The facets of workplace stressors can stem from numerous sources that can or cannot be controlled by the worker. For example, a worker is facing stress due to a difficult task, and he or she can control it through several measures such as asking for support, self-learning or applying better work management. Meanwhile, some stressors cannot be controlled by employers, such as their wage or company policies. These factors are what made workplace stress a challenging issue. The lack of support from colleagues, administrators, and the company could negatively affect the employer, which can cause adverse effects such as low motivation, poor quality work, and missed deadlines. 


\section{Causes of stress among Malaysian Teachers}

Numerous studies have been conducted to identify the causes of teachers' stress. As workplace stress is defined as the inability of employers to cope with job demands than exceed job resources, many studies have concluded that the job demand is the main cause of teachers stress in Malaysia (Ambotang \& Bayong, 2018; Hadi, Naing, Daud, Nordin, \& Sulong, 2009). Another popular cause of stress among teachers is the school administrators, as teachers felt a lack of support by the administrators in helping them manage their job demands (Abu \& Aziz, 2010; Abu Bakar \& Alias, 2020; Halim, Samsudin, Meerah, \& Osman, 2006). Past studies have also found that workload (Ambotang et al., 2014 Raman \& Othman, 2017), school and educational policies (Hadi et al., 2009; Halim et al., 2006) and, workplace environment (Ghani, Che Ahmad, \& Ibrahim, 2013; Marmaya \& Wafa, 2009; Yacob \& Abdullah, 2015) contribute to stress.

Most studies on teachers' stress focused on workplace stress, and therefore studies that looked into teachers' life stress were few and far between. Past studies have shown teachers' stress caused by difficulties in maintaining work-life balance (Yaacob \& Choi, 2015), lack of familial and spousal support (Yaacob et al., 2015. Based on past literature, most studies on teachers' stress highly focused on workplace stress than life stress. Secondly, these past studies have used numerous instruments to investigate the causes of stress among teachers such as self-administered questionnaire (Ambotang \& Bayong, 2018) and adaptation of instrument (Abu Bakar \& Alias, 2020; Hadi et al., 2009). None of these past studies used the Fuzzy-Delphi method in their methodology. Therefore, this study introduced a new angle in research by looking at teachers' stress through the Fuzzy-Delphi method to better understand this issue.

\section{Methodology Participants}

In this study, twenty-nine teachers were interviewed during the group focus step. After each interview, the data patterns were identified and mapped to allow themes to be emerged and developed. Due to the COVID-19 pandemic, schools' visitation was not allowed to ensure that schools received minimal contacts from the outside environment. Therefore, the interviews were conducted via the online platform, either WhatsApp, GoogleMeet and Zoom platform. The average length of the interview was between 30 minutes to 45 minutes. After each interview, the data were transcribed to allow for the themes to emerge. Before the interviews were conducted, the participants' criteria were determined as teachers in either National Primary or Secondary Schools, and they have a minimum of five years of teaching experience

Semi-structured interviews were conducted to allow flexibility in approaching different respondents without disregarding the research area's focus (Hussin, Mohd Nor, \& Suhaimi, 2008). A semi-structured interview also provides room to ask additional questions for clarification. The semi-structured interview questions were developed based on the findings during the extensive literature review and document studies that were conducted before the interview. 


\section{Data Analysis}

\section{Initial Coding Framework}

As the constructs were determined during the extensive literature research, several initial coding frameworks were established to allow the interview to have a standard structure and flow. Table 1.2 below presents the initial coding framework with samples of transcripts representing the themes under the framework. This interview was conducted to see whether the findings of the interview corroborated with the findings of the extensive literature study and also, to unearth any constructs that might be missing in the literature research.

Table 1.1 Initial Coding Framework

Interview Transcript

Initial Coding Framework

I have many responsibilities, I have to Job demands
teach, then manage Koko group,
admin
Sometimes, admin don't know and Administrators
gave us short deadlines.

My workload heavy because I teach Workload

and perform administrative duties

I sometimes feel frustrated by the quick Policy

changes in the education policy.

I think my school need more admin Environment

workers

At home, I still do my work and I don't Work-life balance spend enough time with my children

I think my family knows how busy I am, Lack of familial support but they don't really understand

\section{Coding Process}

Based on Chametzky (2016), the coding process is essential to turn data from description to generalisability. In this study, the coding process was conducted based on the step suggested by Chametzky (2016). In this study, the coding process was run through several steps, including the open coding stage, organising coding stage, comparing coding stage, conceptualising coding stage and theorising coding stage.

\section{Results}

RQ1: What are the causes of stress among Malaysian teachers?

To answer RQ1, the interview was conducted among teachers to identify the causes of stress among Malaysia teachers. Based on the interview, the causes of stress among Malaysian teachers are divided into workplace stress and life stress. The next section elaborates on the causes of stress among Malaysian teachers.

\section{Theme 1: Workplace stress among teachers}

Based on the interview, workplace stress was identified among teachers. Based on the interviews, the sub-themes outlined during the construct definition stage were confirmed, and each theme's classification was refined and generalised. 


\section{Sub-theme 1: Job demand}

The interview found that almost all participants agreed that job demand is one source of stress among teachers. The teachers agreed that being a teacher in Malaysia came with a magnitude of task and responsibilities and these demands cause stress. As T1, T4, and T5 stated:

"Teacher must teach, manage clubs, and do clerical work..." (T1)

"I am doing everything at one time. I need to teach, I need to help admin and also handle students..." (T2)

"I am so busy with classes, and then in the evening I sometimes stay to train students, then doing clerical thing. At night, I need to work too..." (T3)

It was found that under this sub-theme, the teacher usually mentioned teaching, co-curricular activities and, administrative works as the core of their job demands. As T2 stated:

"Usually, my primary job is teaching. Then, I perform administrative duties when I am not in class, I manage co-curricular activity like club, training students to enter competitions..."

T9 also corroborated with the above statement:

"Of course, the main job is to teach the students. Then, admin will ask me to do office work. I also manage co-curriculum, even though the practicum teachers usually help. But, I still need to be there..."

\section{Sub-theme 2: Administrators}

The interview found that participants did feel that the administrators contributed to stress at their work. As explained by T6, T7 and, T10:

"I don't think they understand. They like to interfere while I am doing something because they need help..."

"My admin said one thing but do other thing, I am so stressed..."

"The admin can sometimes bring you down, especially during critical time like exam week..."

Under this sub-theme, there were two major complaints among the teachers: lack of understanding and lack of recognition. T11 and T4 illustrated the lack of understanding by administrators:

"I always feel that principal asked us to do something and asked us to get it done quick. When we said we need time, she said you need to this now, I need to report. I feel like she just ask but do not help..." (T11)

"Admin always ask teacher to do other work when I am busy with other thing. When I said that I need to finish something, she said I need to be flexible. I don't like that..." (T4) 
Meanwhile, the lack of recognition was found to be a dominant issue with administrators. T1, T5, T7 and T9 stated:

"I don't think my principle praised me..." (T1)

"Meeting is complain all time. Very little encouragement..." (T5)

"Maybe the admin is tired too, so they don't really focus on saying good thing, they just want the work to be done..." (T7)

"I wish the admin would say nice thing more often. That will make it less stressful, I think..." (T9)

\section{Sub-theme 3: Workload}

The interview found that participants agreed that they are burdened by an overbearing workload, making them feel stressed. As explained by T2, T5 and, T8:

"I got so much work, especially during sports event and final exam..."

"I haven't finish one thing, I got two more things to do..."

"The workload is heavy. Sometimes I don't think I have time..."

In terms of workload, the teachers felt that their primary duties as teachers are exhausting. T14 described:

"I cannot just come in class to teach. I need to prepare lesson plan, look at the materials and then prepare the homework and mark the homework. Of course, it becomes routine but it is still heavy..."

T6 also described her teaching process as an immense workload:

"A lot to do in teaching. Lesson plan first, then teach. Then, when I give practice or homework, students ask and I cannot answer everyone. When I see wrong answer, I need to checkt.

Other than their duty, the teacher stated that they often were asked to do a job outside their scope. T7 explained:

"Because I am the young male teacher, I have to carry many things. We need to prepare for deco during events or clean the field during sports. Sometimes, I need to fix toilet too..."

"I always have to drive students to competition. I don't want to do it because if anything happens, I will be blamed. So, I am nervous about that. We have to cover other classes too. I want to sit on my desk and mark homework, but I have to watch other students. I am also in 
charge of uniform, so I have to look at the inventory. Usually, that is early year, so I am already busy..."

\section{Sub-theme 4: Policies}

The interview found that participants were stressed about the policy changes in the Education field. As described by T1, T9 and, T13:

"I think policy changes stresses me because I felt that I wasted time on the last policy and suddenly it changes again..." (T1)

"Policy changes get my mood down. And I feel it slow my teaching too..." (T9)

"I don't like when policy is changing too fast. I always have to adjust my teaching..." (T13)

Based on the interview, the stress caused by policy change manifested in the change and the lack of support given to handle these changes. As T4 and T11 explained:

"Usually, when a change happened, they just give document and some materials. The rest we have to figure it out. Coaching would come a bit late, I sometimes feel sorry for students..." (T4)

"I remember when teaching Maths in English happened. I think my English teacher friend did try to help but I would like it more if admin arrange for something sooner. Or maybe, tell us early so we can practice..." (T11)

\section{Sub-theme 5: Environment}

The interview found that participants agreed that the environment contributed to stress at their work. As explained by T8, T10 and, T14:

"I think the school should do a lot more to help with our stress..."

"Coming to school can be really stressful..."

"School environment is tough on me..."

The primary environmental concern among the teachers is the colleagues' dynamic. Some teachers felt that their mismatch personalities contributed to their stress level. As stated by T3 and T5:

"I am a loner, so I don't talk to my colleagues. So, sometimes doing work with them is stressful because we are different..."

"Some other teachers like to talk freely. They were also teachers who is difficult to work together. Sometimes I have to argue with them, and my mood is off all day..."

Secondly, the students' behaviours did cause stress in their work. However, teachers felt that these students can also be their source of strength. T8 and T11 explained: 
"Students can sometimes misbehave, and it did make me angry. But they are kind as well. So, they can make me stressed, but they are also helpful..."

"You know, they like to play with us. Sometimes pick the wrong time to play. Sometimes, they make me angry too, like when they want to play a little near the exam or they take a long time to settle down. I am stressed but these students are cute so, they are all right..."

Lastly, the environment caused teachers to feel stressed due to the school's lack of supporting materials and lack of administration staff. Based on T6, who was an English teacher:

"I think school need to have an audio room, so it is easier to do listening exercise. School have limited supplies and we have to do a lot on our own. I hope school can supply more materials..."

Also, T9, who was a Maths teacher, said:

"If the school can have a collection of exercise to give to us, we can save more time. Weak students can have more practice and it can help them. I think school should help in supplying classroom materials. Parents usually help bought stuff like brooms, wrapping paper, class deco. If the class do not have rich parents, class can be a bit dull and yes, your mood will be down too..."

T11 described the issue of lack of administration staff:

"School really needs to have admin staff. Teachers cannot do clerical work always, we need to focus in class. I feel if my school have more admin workers, I will be less stressful..."

The last factor under the environment sub-theme is the lack of promotion or career advancement in their job. T6 and T10 mentioned this:

"I feel that I have been carrying the same title for so long. It is mundane and boring..."

"I don't know if I can last being a teacher because I just repeating the same thing every year..."

\section{Theme 2: Life stress among teachers}

Based on the interview, the teachers are also affected by life stress as well. As mentioned earlier, most studies focus on workplace stress and therefore, life stress among teachers were rarely documented. The interview has detailed the life stress that was faced among teachers. Also, this interview has identified two additional sub-themes under the life stress theme.

\section{Sub-theme 1: Work-life balance}

The interview with the teachers revealed that balancing their job and the home was a cause for stress. T3, who was a single mother, explained:

"I am all my son have, so balancing everything is very stressful. He is very young too, so he needs my help..." (T3)

Another teacher, T4, stated: 
"I don't like to mark homework at home. But, I need to do it because I cannot do it in school and I cannot look at my children's homework..." (T4)

The work-life balance issue was also seen in a single teacher, as stated by T1:

"I have a lot of works so my life is school and home. I don't go out to see my friends on weekend because I am too tired or I still have to be at school or I need to catch up work..." (T1)

\section{Sub-theme 2: Lack of familial support}

During the interviews it was found that the teachers felt that their family or spouse did not fully understand their job as teachers. As explained by T2 and T8:

"I live with my parents and when I only stay in my room, they think I don't want to talk. I want to talk but I am too tired, and I want to sleep..."

"My husband is far away so I can only talk over the phone. I knew he listened but I don't think he understand..."

However, this issue was less severe among spousal with similar job characteristics. As explained by T6:

"Yeah, we argue about job and home, but he can understand when I have to bring work at home. He is a lecturer at college, so he gets busy during finals too..."

\section{Sub-theme 3: Financial Problem}

This sub-theme was discovered during the interview. Teachers were found to state that the financial issue was one of the causes of stress. This sub-theme was found when teachers were explaining previous sub-themes. As explained by T6:

"I feel sorry for students during listening exercise, so I bought my own speaker. I always use my own money to buy teaching supplies. I wish I can use my money for myself, but I used it for school stuff..."

T9 elaborated:

"I also put my own money to help my classroom. I want to feel happy when I enter my class so I got wrapping papers and deco. I cannot get reimbursed for it, so after so many classes, that is stressful..."

T8, who lived far away from her husband, explained:

"Because my husband is far from me, I have to drive to see him. My transfer application is not approved, so I felt that my money is wasted on travel..."

\section{Sub-theme 4: Life Events}

Another factor that was discovered during the interview was life events. Teachers in the interview explained that life events could cause abrupt stress in their work, specifically when 
the timing of the events clashed with critical weeks in school. As described by T2, T10 and, T12:

"I got dengue during exam week, so I was sick, but I cannot relax because I kept thinking of my students..." (T2)

"I lost my father at the beginning of my fourth year of teaching. So, I have to handle new class when I was mourning my father..."(T10)

"The timing can be so bad. Like one time, my husband got a transfer during the week when we need to have SPM study camp..." (T12) RQ2: What are the constructs for causes of stress in the Stress Index for Teachers in Malaysia?

To answer RQ2, the findings of the interview were coded and assigned to themes. Based on the coding framework, the construct for the Stress Index is presented in figure 1.1 below.

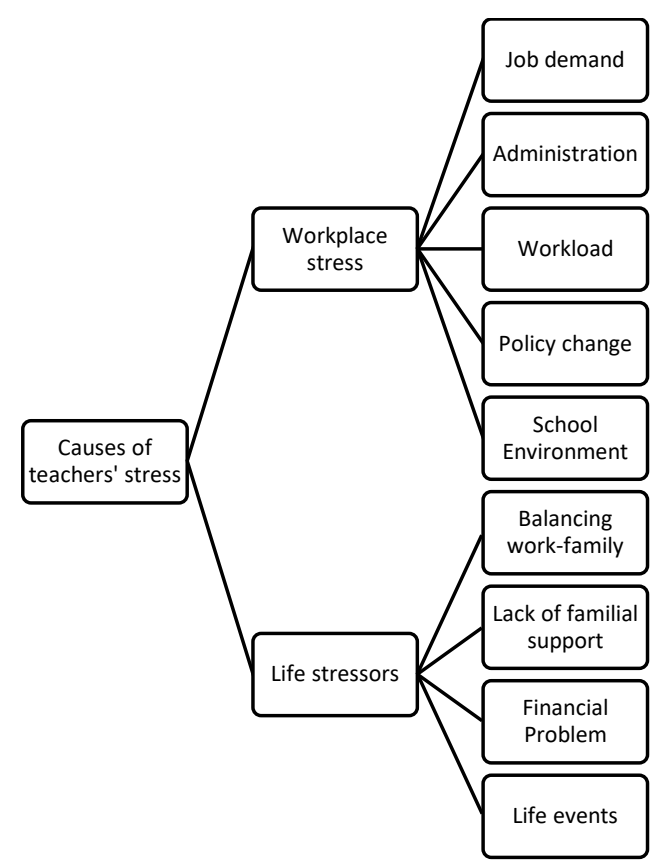

Figure 1.1: The construct for causes of stress among teachers in the Stress Index

Based on figure 1.1, the construct of causes of stress among teachers is divided into two major themes, workplace stress and life stress. Under the workplace stress, five sub-themes were identified, job demand, administration, workload, policy change and school environment. For the second theme, life stress, four sub-themes were identified, balancing work-family, lack of familial support, financial problem and life events.

\section{Discussion}

The study has helped expand the literature by introducing two new sub-themes under the life constructs: financial problem and life. This study also helps in understanding the issue of teachers' stress using the Fuzzy Delphi method. The interview has revealed that the study of teachers' stress is far from finished, and they were still grey areas that need to be covered and investigated. This study also showed the dire need to have a stress index using the FuzzyDelphi method. The Fuzzy-Delphi method is a thorough method that combines rigorous, 
relevant research literature, the old root of interview data, and a Fuzzy Delphi expert questionnaire that ensures a complete and comprehensive index (Mei, Hsu, \& Ou, 2020). Also, an index that investigated teachers' stressors other than just evaluating the level of teachers' stress is essential to understand the issue better

\section{Limitations and Future Studies}

There were several limitations found in this study. Firstly, the selection of participants was quite restricted due to the Covid19 pandemic. Most of the teachers were initially reluctant to be interviewed because they were also busy adjusting their teaching during the pandemic, which required them to prepare online lessons. For future studies, it is suggested that all stakeholders be involved in the initial stage to identify stress indicators, such as administrators, Teachers of Special Needs Students, Teachers Union Representatives, Parents teachers Association Representatives. Another suggestion for future study is to expand the study to cover a wider geographical area to get a closer finding that reflects the research population.

\section{Conclusion}

This study aims to identify the causes of stress among Malaysian teachers and identify the construct for causes of teachers' stress in the Stress Index. During this step, twenty-nine teachers were interviewed to provide an in-depth explanation of the causes of stress among teachers. The interview confirmed the constructs developed during literature research and introduce two new sub-themes to the construct of teachers' stressors. With the finalisation of the construct during the construct definition step, the next step to determine the constructs' validity and reliability could be carried out in the next phase of the study.

\section{Acknowledgement}

This research is funded by UiTM under the FRGS Grant Scheme - 600IRMI/FRGS/5/3/(076/2019). The authors would like to thank KPT for the grant and PJI UiTM Melaka for their support and assistance in completing this paper. The authors would like to acknowledge the contribution of T3, who sadly passed away shortly after the interview for this study.

\section{References}

Abdul Muin, S. (2005). Stres Guru Membimbangkan - Akibat Banyak Perubahan dan Bebanan Tugas Yang Keterlaluan. Stres Guru Membimbangkan - Akibat Banyak Perubahan dan Bebanan Tugas Yang Keterlaluan. NUTP.

Abu, B., \& Aziz, M. (2010). Stress Dalam Kalangan Guru di Dua Buah Sekolah Menengah Kebangsaan di kawasan Skudai. Fakulti Pendidikan, Universiti Teknologi Malaysia, Skudai.

Ambotang, A. S., \& Bayong, N. (2018). The Relationship between the Burden of Duties and Stress Towards Teacher's Commitment at the Primary School. Jurnal Bitara UPSI, 11(1), 11-21.

Bakar, M. K. B. A., \& Alias, B. S. (2020). Hubungan antara Kepimpinan Multidimensi Guru Besar dan Kepuasan Kerja Guru. Jurnal Pendidikan Malaysia, 45(1SI), 35-41.

Chametzky, B. (2016). Coding in Classic Grounded Theory: I've done an interview; now what? Sociology Mind, 6, 
Epel, E. S., Crosswell, A. D., Mayer, S. E., Prather, A. A., Slavich, G. M., Puterman, E., Mendes, W. B. (2018). More than a feeling: a unified view of stress management for population science. Front Neuroendocrinol, 49, 146-169.

Ghani, M. Z., \& Ahmad, A., \& Ibrahim, S. (2013). Stress among Special Education Teachers in Malaysia. 4th World Conference on Psychology, Counselling and Guidance WCPCG2013 (pp. 4-13). Elsevier Ltd.

Goyal, M., \& Arora, S. (2012). Harnessing work: family life balance among teachers in educational institutions. International Journal of Applied Services Marketing Perspectives, 1(2), 170-178.

Hadi, A. A., Naing, N. N., Daud, A., Nordin, R., \& Sulong, M. R. (2009). Prevalance and factors associated with stress among secondary school teachers in Kota Bharu, Kelantan, Malaysia. The Southeast Asian Journal of Tropical Medicine and Public Health, 40(6), 1359-1370.

Haggard, C., Slostad, F., \& Winterton, S. (2006). Transition to the school as workplace: Challenges of second career teachers. Teaching Education, 17(4), 317-327.

Halim, L., Samsudin, M. A., Maerah, T. S. M., \& Osman, K. (2006). Measuring science teachers' stress level triggered by multiple stressful conditions. International Journal of Science and Mathematics education, 4(4), 727,739.

Hasan, A. A., Elsayed, S., Tumah, H. (2018). Occupational stress, coping strategies and psychological-related outcomes of nurses working in psychiatric hospitals. Perspect Psychiatr Care.

Hassard, J., Teoh, K. R., Visockaite, G., Dewe, P., \& Cox, T. (2018). The cost of work-related stress to society: A systematic review. Journal of occupational health psychology, 23(1), 1 .

Henry, J., \& Crawford, J. (2005). The short-form version of the Depression Anxiety Stress Scale (DASS-21): Construct validity and normative data in a large non-clinical sample. British Journal of Clinical Psychology, 44(2),227-239.

Hussin, H., Nor, R. M., Suhaimi, M. A. (2008). Perceived attributes of e-commerce and the adoption decision: The case of Malaysian SMEs. Asia-Pacific Journal of Information Technology and Multimedia, 5(1).

Liu, W.-K. (2013). Application of the Fuzzy Delphi method and the Fuzzy Analytic Hierarchy process for the managerial competence of multinational corporation executives. International Journal of e-Education, e-Business, e-Management and e-Learning, 3(4).

Lovibond, S. H., \& Lovibond, P. F. (1995). Manual for the Depression Anxiety Stress Scale. Sydney: Sydney Psychology Foundation Australia.

Marmaya, N. H., \& Wafa, S. A. (2009). The role of demographic variables as the moderator between organizational variables and job stress among teachers in Sabah. Social and Management Research Journal, 6(1), 1-13.

Masilamani, R. Darus, A., Ting A. S., Ali, R., Mahmud, A.B., \& David, K. (2012). Salivary biomarkers of Stress among teachers in an urban setting. Asia-Pacific Journal of Public Health, 24(2), 278-287. doi:https://doi.org/10.1177/1010539510393725

Musa, N. A., Moy, F. M., \& Wong, L. P. (2018). Prevalence and factors associated with poor sleep quality among secondary school teachers in a developing country. Industrial health. doi:https://doi.org/10.2486/indhealth.2018-0052

Othman, Z., \& Sivasubramaniam, V. (2019). Depression, anxiety, and stress among secondary school teachers in Klang, Malaysia. Int Med J, 26(2), 71-74. 
Punia., V., \& Kamboj, M. (2013). Quality of work-life balance among teachers in higher education institutions. Learning Community, 4(3), 197-208.

Raman, B., \& Othman, N. (2017). Workload factor encouraging job stress among PT3 teachers in School DIstrict Kapit, Sarawak. Proceedings of 57th IASTEM International Conference. Kota Kinabalu.

Slavich, G. M. (2016). Life stress and health: a review of conceptual issues and recent findings. Teach Psychol, 43, 346-355.

Tan, S. Y., Yip, A. (2018). Hans Selye (1907-1982): Founder of stress theory. Singapore Medical Journal, 59(4), 170.

Whitehead, A. J. (2001). Teacher burnout: a study of occupational stress and burnout in New Zealand school teachers. Teacher burnout: a study of occupational stress and burnout in New Zealand school teachers. Massey University, Albany, New Zealand: a thesis submitted in partial fulfilment of the requirements for the degree of Doctor of Philosophy.

World Health Organization. (2007). Occupational Health. Retrieved from World Health Organisation: https://www.who.int/occupational_health/topics/stressatwp/en/

Yaacob, M., \& Choi, S. L. (2015). Role of Occupational Stress on Job Satisfaction. Mediterranean Journal of Social Sciences, 6(2). doi:10.5901/mjss.2015.v6n2s1p81

Yacob, Z. M., \& Abdullah, Z. (2015). Effects of a Female Principal's Leadership Style on Teachers' Work Stress. Educational Leader (Pemimpin Pendidikan), 3, 123-137.

Zamri, E. N., Moy, F. M., \& Hoe, V. C. (2017). Association of psychological distress and work psychological factors with self-reported musculoskeletal pain among secondary school teachers in Malaysia. Plos one, 12(2), e0172195. doi:https://doi.org/10/1371/journal.pone.0172195

Zarisfizadeh, S. (2012). Job Satisfaction Factors among English Language Teachers in Malaysia. International Journal of Applied Linguistics \& English Literature, 1(4) 30. 